\title{
MFGE8 Gene
}

National Cancer Institute

\section{Source}

National Cancer Institute. MFGE8 Gene. NCI Thesaurus. Code C24592.

This gene plays a regulatory role in the phagocytosis of apoptotic cells. 